\title{
Negara Maritim Indonesia, Migrasi Tidak Teratur, dan Hak Pengungsi Lintas Batas
}

\author{
Nurul Azizah Zayzda, Sri Wijayanti ${ }^{1}$
}

\begin{abstract}
Abstrak
Makalah ini membahas kebijakan Indonesia sebagai sebuah negara maritim dalam menghadapi persoalan migrasi tidak teratur, khususnya disini yang berdampak pada pencari suaka dan pengungsi lintas batas. Isu migrasi tidak teratur masih merupakan persoalan yang dihadapi oleh negara maritim yang memiliki akses terbuka berupa laut yang menjadi jalur utama perjalanan migran menuju negara tujuan. Sebagai negara yang terletak di jalur pelayaran utama dunia, di tengah tengah benua Australia dan Asia, Indonesia seringkali dihadapkan pada persoalan ini dimana Indonesia menjadi jalur atau negara transit pengungsi dan pencari suaka yang kebanyakan datang dari wilayah Timur Tengah dan Asia Selatan. Menurut data UNHCR, saat ini terdapat sekitar 13 ribu pengungsi dan pencari suaka di Indonesia, dan jumlah ini meningkat dari tahun-tahun sebelumnya. Indonesia sebagai negara maritim memiliki prinsip bahwa kepulauan dan kelautan Indonesia merupakan satuan pertahanan dan keamanan Indonesia (Zen, 2000, dikutip dari Geomagz, 2016). Namun penting untuk lebih jauh melihat bagaimana prinsip ini memandang hak asasi manusia dalam isu krisis kemanusiaan seperti pengungsi lintas batas dan pencari suaka. Makalah ini bertujuan untuk menjelaskan bagaimana karakter kemaritiman yang diambil Indonesia berpengaruh terhadap cara Indonesia menyikapi pengungsi lintas batas yang melakukan perjalanan dengan penyelundupan manusia. Makalah ini dibatasi lebih lanjut kepada bentuk kerjasama internasional untuk menangani penyelundupalajan manusia yang diinisiasi oleh atau melibatkan Indonesia. Dari sini kemudian ditarik kesimpulan mengenai hambatan pemenuhan hak pengungsi lintas batas dalam sistem internasional yang berdasarkan kedaulatan negara-bangsa.
\end{abstract}

Kata-kata kunci: negara maritim, penyelundupan manusia, hak-hak pengungsi lintas batas, pencari suaka.

\begin{abstract}
This paper discusses the policy of Indonesia as a maritime country in addressing the issue of irregular migration, especially that impact on asylum seekers and refugees. The issue of irregular migration is still faced by maritime nations that have open access in the form of sea which became the main route of migrant journey to the destination country. As a country located in the world's major shipping lanes, in the middle of the continent of Australia and Asia, Indonesia is often faced with this problem given that Indonesia is a transit country of refugees and asylum seekers mostly from the Middle East and South Asia. According to data from UNHCR, there are currently about 13 thousand refugees and asylum seekers in Indonesia, and this number increased from previous years. Indonesia as a maritime country has a principle that Indonesia is an archipelago while maritime is part of its defense and security unit (Zen, 2000, cited from Geomagz, 2016). However it is important to further see how this principle oversees the issue of human rights in humanitarian crises such as refugees and asylum seekers.

This paper aims to explain how the maritime character of Indonesia affects its ways to address refugee travel with people smuggling. This paper is further limited to the forms of international cooperation to tackle human smuggling initiated by or involving Indonesia. The obstacles to meet the refugee rights in the international system that is based on the sovereignty of the nation-state is then concluded.
\end{abstract}

\section{Pendahuluan}

Indonesia adalah negara kepulauan yang terletak di jalur pelayaran utama dunia yaitu Samudera Hindia dan Samudera Atlantik dan diapit oleh benua Asia dan benua Australia. Kapalkapal yang hendak berlayar menuju Australia akan memasuki wilayah perairan Indonesia, begitu juga sebaliknya, jika kapal-kapal akan berlayar ke benua Asia maka mereka akan melewati perairan Indonesia. Jalur pelayaran

${ }^{1}$ Staf Pengajar Jurusan Hubungan Internasional, FISIP, Universitas Jendral Soedirman. 
ini menimbulkan berbagai macam konsekuensi, antara lain keuntungan secara ekonomi, politik dan juga sosial. Secara ekonomi dapat terlihat dari ramainya pelabuhan-pelabuhan besar di Indonesia yang memberikan banyak pemasukan dari bersandarnya kapal-kapal asing. Secara politik, Indonesia memiliki posisi tawar dalam berbagai perundingan dan kerjasama yang dilakukan dengan negara-negara lainnya. Begitu juga dengan banyaknya kapal asing yang bersandar di Indonesia menimbulkan asismilasi dan akulturasi budaya baru yang berdampak secara sosial.

Dalam perjalanannya, Indonesia sempat mendeklarasikan konsep Benua Maritim Indonesia, sebuah konsep mengenai wawasan nusantara yang dideklarasikan oleh Soeharto dalam Konvensi Nasional Benu Maritim Indonesia di kota Makassar, Sulawesi Selatan tahun 1996. Dalam konvensi ini turut menandatangani Deklarasi Benua Maritim Indonesia adalah Menko Polkam, Sekretaris Jenderal Dewan Pertahanan nasional, Ketua Dewan Pertahanan Nasional, Menteri Riset dan teknologi sekaligus Ketua BPPT dan Ketua Harian Dewan Kawasan Timur Indonesia dan Ketua Sub Panitia Dewan Kawasan Timur Indonesia untuk Sumberdaya Alam dan Lingkungan Hidup. Konsep Benua Maritim Indonesia memandang bahwa negara Indonesia merupakan wilayah yang bukan hanya berbentuk kepulauan saja, namun juga sebuah kesatuan yang terdapat di dalamnya, baik di udara, laut dan yang ada di dalam bumi. Hal ini berarti hamparan laut yang berada dalam jarak tertentu yang diukur dari bibir pantai Indonesia yang diakui oleh perjanjian internasional merupakan bagian yang tidak terpisahkan dari Indonesia sebagai negara kepulauan. Pengakuan ini dilegalisasikan dalam ratifikasi United Nations Convention on The Law of The Sea (UNCLOS). Konvensi ini mengakui bahwa Indonesia memiliki laut dalam, Zona ekonomi Ekslusif (ZEE) dan zona tambahan. Indoonesia memiliki kekuasaan atas laut dalam, ZEE dan zona tambahan di perairan sekitarnya yang berbatasan dengan bibir pantainya. Konvensi internasional UNCLOS, memnimbulkan sebuah batas-batas baru dalam perairan suatu negara. Indoenesia memiliki hak kedaulatan dalam menjaga perairannya.

Potensi persoalan yang muncul di wilayah perairan adalah penyelundupan manusia, perdagangan manusia dan perpindahan pencari suaka. Permasalah tentang migrasi tidak teratur ini menjadi salah satu permasalahan yang muncul antara Indonesia dengan Australia. Hal ini dikarenakan Australia menjadi salah satu negara tujuan para pengungsi lintas batas dari negara-negara Timur Tengah dan Asia Selatan yang terkena konflik. Indonesia merupakan negara transit utama bagi pengungsi lintas batas yang mencari suaka ke Australia. Menurut data UNHCR, saat ini terdapat sekitar 13 ribu pengungsi dan pencari suaka di Indonesia, dan jumlah ini meningkat dari tahun-tahun sebelumnya. Para pengungsi lintas batas yang berasal dari Iran, Afghanistan, Pakistan, 
Bangladesh, Myanmar, Sri Langka, Malaysia; setelah itu mereka ke Pulau Christmast untuk menuju Australia. Dalam 10 tahun terakhir sampai dengan 31 Desember 2015, 139,398 pengungsi telah berada di Australia (Refugee Council, 2015).

Berdasarkan latar belakang ini, makalah ini membahas lebih lanjut mengenai keterkaitan antara konsep negara maritime dengan hak-hak dari pengungsi lintas batas, khususnya dalam upaya mereka mencari suaka. Pembahasan dilakukan dengan melihat perkembangan konsep kemaritiman di Indonesia dan kebijakan mengenai imigrasi dan keamanan perbatasan yang mengiringinya. Kebijakan mengenai imigrasi dan keamanan perbatasan ini kemudian dilihat tidak hanya dari UndangUndang atau hukum nasional namun juga keikutsertaan Indonesia dalam forum internasional atau regional serta bentuk kerjasama bilateralnya dengan negara yang berbatasan laut dengannya seperti Australia. Dan terakhir, makalah ini menyimpulkan bagaimana rangkaian kebijakan dan sikap Indonesia ini berpengaruh terhadap pembentukan retorika mengenai hakhak pengungsi lintas batas untuk mencari perlindungan.

\section{Permasalahan}

"Bagaimana hak-hak dari pengungsi lintas batas diterapkan oleh Indonesia sebagai negara maritim dalam menangani penyelundupan manusia?"

\section{Kerangka Konsep}

Untuk menjawab rumusan masalah yang diberikan di atas, pembahasan dalam makalah ini akan dibantu dengan menggunakan konsep perlindungan internasional terhadap pengungsi lintas batas, serta konsep migrasi tidak teratur.

\section{Migrasi Tidak teratur: Penyelundupan}

\section{Manusia}

Menurut International Organization for Migration (IOM), definisi migrasi tidak teratur adalah:

"Pergerakan manusia yang terjadi diluar norma-norma atau aturan yang berlaku di negara asal, negara transit dan negara penerima. Tidak ada definisi dari migrasi tidak teratur yang jelas atau berlaku secara universal. Dari sudut pandang negara tujuan, migrasi ini adalah proses orang-orang masuk, tinggal atau bekerja di sebuah negara tanpa dokumen atau izin yang dibutuhkan sesuai UU imigrasinya. Dari perspektif negara asal, ketidakteraturan ini dapat dilihat dari kasuskasus dimana seseorang menyebrangi perbatasan internasional tanpa paspor atau dokumen perjalanan yang valid dan tidak memenuhi perlengkapan administrative yang dibutuhkan untuk meninggalkan suatu negara. Bagaimanapun, terdapat kecenderungan untukmembatasi penggunaan kata "migrasi illegal" pada kasus-kasus seperti penyelundupan migran atau perdagangan manusia."

Penggunaan kata migrasi illegal 
dihindari karena konotasinya yang dekat dengan kriminalitas (Migrant Rights Network, 2009). Migrasi tidak teratur merupakan fenomena yang kompleks, melingkupi berbagai bentuk migrasi (pencari suaka/pengungsi lintas batas, migrasi pekerja, baik itu dengan jalur penyelundupan atau menjadi korban perdagangan manusia), dengan berbagai latar belakang dimana, menyebut mereka semua sebagai pelanggar hukum atau pelaku kriminal adalah penyebutan yang terlalu menyederhanakan.

Menurut Protokol PBB terhadap Penyelundupan Migran melalui jalur Darat, Air dan Udara, pelengkap dari Konvensi PBB terjadap Tindak Kriminal Transnasional Terorganisir, penyelundupan manusia adalah "Proses pembelian/pencarian untuk mendapat, langsung maupun tidak langsung, keuntungan finansial atau materi lainnya, dari masuknya seseorang secara illegal ke suatu bagian negara dimana orang tersebut bukanlah warga negara atau memiliki izin tinggal". Sementara itu definisi perdagangan manusia menurut Protokol PBB untuk Mencegah, Menekan dan Menghukum Pedagang Manusia, terutama Wanita dan Anak-anak sebagai pelengkap Konvensi PBB terjadap Tindak Kriminal Transnasional Terorganisir adalah "perekrutan, pengiriman, pemindahan, penampungan, atau penerimaan seseorang, dengan ancaman atau penggunaan kekerasan atau bentuk-bentuk lain dari pemaksaan, penculikan, penipuan, kebohongan atau penyalahgunaan kekuasaan atau posisi rentan atau memberi atau menerima pembayaran atau memperoleh keuntungan agar dapat memperoleh persetujuan dari seseorang yang berkuasa atas orang lain, untuk tujuan eksploitasi". Perbedaan mendasar antara penyelundupan manusia dengan perdagangan manusia adalah aspek kekerasan dan eksploitasi yang terdapat pada perdagangan manusia dan tidak terdapat pada penyelundupan manusia.

Dalam makalah ini, penyelundupan manusia dilihat sebagai sebuah jalur atau metode perjalanan yang diambil pengungsi lintas batas untuk sampai ke suatu negara karena keterbatasan mereka untuk mendapatkan dokumen perjalanan yang sah. Dengan cara pandang ini, makalah ini ingin melihat bagaimana kebijakan dan aturan yang dianggap normal sesungguhnya memiliki pengaruh secara langsung atau tidak langsung pada pengungsi lintas batas melalui retorika mengenai metode perjalanan mereka yang dibuat oleh kebijakan yang ada.

\section{Perlindungan Pengungsi Lintas Batas}

Definisi dari refugee atau pengungsi lintas batas dijelaskan dalam Konvensi Jenewa tahun 1951 mengenai Status Pengngsi Lintas Batas dan Protokol tahun 1964. Disini, pengungsi lintas batas dijelaskan dalam Pasal 1 Ayat 2 sebagai orang-orang yang:

"Sebagai akibat peristiwa-peristiwa yang terjadi sebelum 1 Januari 1951 dan disebabkan oleh ketakutan yang beralasan 
akan persekusi karena alasan-alasan ras, agama, kebangsaan, keanggotaan pada kelompok sosial tertentu atau opini politik, berada di luar negara kewarganegaraannya dan tidak dapat, atau karena ketakutan tersebut tidak mau memanfaatkan perlindungan negara itu, atau seorang yang tidak mempunyai kewarganegaraan dan karena berada di luar negara dimana ia sebelumnya biasanya bertempat tinggal, sebagai akibat peristiwaperistiwa termaksud, tidak dapat atau, karena ketakutan tersebut, tidak mau kembali ke negara itu."

Definisi ini mencakup setiap orang yang menjadi korban atau terdampak oleh situasi konflik atau pemerintahan totaliter yang merepresi warganegara atau kelompok identitas tertentu dengan kekerasan.

Konvensi ini kemudian mengatur kewajiban negara untuk memberikan perlindungan bagi pengungsi lintas batas yang sudah terbukti memang melarikan diri dari ancaman bahaya. Kewajiban ini adalah untuk memberikan tempat tinggal dan memenuhi hak-hak dasarnya sebagai manusia. Di samping itu, untuk pencari suaka, yakni pengungsi lintas batas yang belum mendapat status resmi dari UNHCR, negara wajib menjamin hak mereka untuk bermigrasi dengan aturan mengenai:

1. Proses masuk Ilegal. Di dalam pasal 31 dijelaskan bahwa negara harus mengijinkan pengungsi lintas batas yang tidak memiliki dokumen perjalanan untuk masuk ke negaranya tanpa mendapat hukuman atau sanksi

2. Prinsip non-refoulment. Di dalam pasal 33 diatur bagaimana pengungsi lintas batas tidak boleh dipulangkan ke negara asal dimana mereka terancam kekerasan (IPU dan UNHCR, 2001).

Hak pengungsi lintas batas yang akan dibahas secara khusus dalam makalah ini adalah hak mereka untuk mencari perlindungan, yakni ketika mereka masih berstatus pencari suaka (belum mendapat status pengungsi dari UNHCR). Hak ini meliputi hak untuk masuk atau melintasi batas negara tanpa mendapat penalty dan hak untuk tidak dipulangkan.

Namun, kewajiban ini hanya akan melekat pada negara yang sudah menandatangani dan meratifikasi protokol ini. Indonesia, sementara itu tidak pernah menandatangani protocol ini, sehingga tidak ada kewajiban bagi Indonesia dalam hukum internasional. Oleh karena itu, dalam makalah ini, hak pengungsi lintas batas akan dibahas dalam komitmen Indonesia dalam HAM selaku negara yang patuh terhadap Deklarasi Universal mengenai HAM. Di samping itu, juga bagaimana Indonesia memastikan hak pencari suaka seperti disebutkan di atas setidaknya bisa dijamin di Indonesia dan negara yang terhubung langsung dengan Indonesia dalam isu penyelundupan pengungsi lintas batas, yakni Australia.

Tulisan ini mengikuti alur pemikiran penulis-penulis mengenai hak orang asing atau pengungsi dan penulis mengenai batasan penerapan HAM secara internasional, dan khu- 
susnya pada pengungsi lintas batas seperti Benhabib (2004, 2006), Chandler (2002), dan Haddad (2003, 2008). Berangkat dari pemikiran Benhabib (2004) bahwa sistem negara-bangsa modern terjebak di antara kedaulatan dan hospitality makalah ini mengkritisi bagaimana kebijakan normal mengenai kedaulatan yang diejawantahkan dalam berbagai doktrin termasuk doktrin maritime memberi hambatan bagi pemenuhan hak pengungsi lintas batas. Chandler (2002) menjelaskan bahwa masalah penerapan hak perlindungan pada akhirnya terlalu bergantung pada negara atau institusi internasional, bukan pada pemegang haknya. Hal serupa disampaikan Haddad (2008) bahwasanya pengungsi lintas batas terjebak dalam sistem negara-bangsa yang menyebabkan mereka akan selalu dipandang sebagai ancaman pada mode negara-bangsa yang tertata ini. Khususnya, Haddad (2003) menyebut kedaultan sebagai "otonomi eksternal" yang pada makalah ini akan dijelaskan, bahwa penggunaan kata "penyelundupan" adalah cara negara mempertegas “otonomi eksternal"-nya.

\section{Pembahasan}

Bahwa penyelundupan manusia merupakan salah satu jalur yang digunakan pengungsi lintas batas untuk meninggalkan bahaya dan mencari tempat yang lebih aman menjadi suatu masalah bagi negara yang mereka masuki, termasuk Indonesia adalah dikarenakan adanya hukum yang membuat mereka sebagai pelanggar hukum. Pertanyaannya adalah, apakah arti penting konsep negara maritim yang sedang dipergunakan Indonesia bagi perjalanan korban krisis kemanusiaan ini?

\section{Perkembangan Konsep Negara Maritim In- donesia dan Prinsip Keamanan}

Untuk menjelaskan apa yang dimaksud dengan negara maritim, makalah ini menggunakan definisi yang diberikan Rosyid (2015), yakni "negara yang mampu mengelola kepentingan maritimnya secara efektif demi kedaulatan politik, dan kemandirian ekonominya. Kepentingan maritim adalah kepentingan pemanfaatan laut sebagai ruang kehidupan (lebensraum)" (Rosyid, 2015: 75).

Joko Susanto (2015) menjelaskan perkembangan konsep kemaritiman Indonesia semenjak kemerdekaan. Pasca kemerdekaan, Indonesia menggunakan prinsip archipelago atau kepulauan, yang dihasilkan dari Deklarasi Juanda. Dasar dari penggunaan doktrin kepulauan ini adalah kebutuhan Indonesia untuk menjaga persatuan Indonesia yang kala itu rentan dengan pemberontakan daerah. Kemudian pada periode Orde baru, doktrin kepulauan ini diperbaiki dengan memberikan perhatian pada sumber daya alam di kawasan lepas pantai. Periode baru Doktrin Kepulauan ini menghasilkan Deklarasi Landas Kontinen dan Deklarasi Zona Ekonomi Eksklusif. Pada tahun 1970-an, doktrin kepulauan berangsur digantikan oleh doktrin "wawasan nusantara".

Konsep Benua Maritim Indonesia kemudian muncul pada tahun 1996, menjelang akhir dari rezim pemerintahan Soeharto. Pada periode inilah di Indonesia muncul kembali wacana untuk mengarahkan doktrin pembangunannya dari yang terpusat kepada dara- 
tan untuk kembali ke lautan. Mengenai konsep Benua Maritim Indonesia ini dijelaskan dalam Majalah online Geomagz terbitan Kementerian ESDM dengan menyarikan makalah dari Zen (1999, 2000). Disana dituliskan:

Bangsa Indonesia harus "hidup dari dan dengan Laut".Inilah doktrin kelautan Indonesia. Secara konkrit, ini berarti bahwa lautan itu merupakan: (i) sumber nafkah (sumber protein dan sumber energi); (ii) sumber kesempatan kerja; (iii) sumber pengembangan kekuatan ekonomi; (iv) sumber pengembangan sains dan teknologi; (v) sumber atau lahan untuk mengatur siasat dan seni pertahanan; (vi) unsur pemersatu; dan (vii) sumber inspirasi bagi seniman, ilmuwan, negarawan, dan pemikir (Zen, 2000, dikutip dalam Geomagz, 2016).

Pokok pemikiran Benua Maritim Indonesia disini adalah mengenai bagaimana menjalankan nadi perekonomian negara (poin i-iii). Seiring dengan itu, 'doktrin kelautan' ini membutuhkan penguatan perkembangan ilmu pengetahuan di bidang kelautan, untuk mewujudkan kesejahteraan melalui laut tadi (poin iv). Sebagai konsekuensinya juga adalah akan dibutuhkan pendekatan-pendekatan baru dalam pertahanan dengan perhatian yang ditingkatkan pada wilayah laut (poin v). Untuk membuat wawasan maritim ini dapat bersifat menyeluruh, maka perlu diperkuat pandangan bahwa lautan bukan pemisah melainkan jembatan antar kawasan. Disini laut dikaitkan erat dengan semangat nasionalisme. Berbagai sara- na dapat digunakan untuk memperkuat pengetahuan baru dan semangat ini, selain melalui penelitian-penelitian ilmiah juga adalah melalui karya seni yang dapat diserap khalayak umum.

Susanto (2015) melihat bahwa kecenderungan Indonesia secara umum dalam hal maritime bersifat "meruncing ke dalam", dilakukan hanya dengan memastikan integrasi territorial dan ketahanan nasional dari ancaman luar. Barulah ada periode reformasi sementara itu, Indonesia memperlihatkan kecenderungan "maritimisasi" territorial, walaupun sifatnya masih sangat sporadis (Susanto, 2015). Munculnya konsep Indonesia sebagai "Poros Maritim Indonesia" pada tahun 2014, bisa dikatakan sebagai hasil dari perjalanan maritimisasi semenjak reformasi ini.

Makalah ini berargumen bahwa konsep negara maritim, sebagaimana terlihat dalam perkembangannya di Indonesia secara tidak langsung memberikan fondasi bagi negara untuk mengesampingkan hak-hak pengungsi lintas batas dalam mencari suaka. Saat ini, semua imigran yang masuk ke Indonesia, tanpa peduli latar belakangnya akan diatur berdasarkan Hukum Keimigrasian Indonesia. Undangundang yang berhubungan dengan Keimigrasian yang berlaku saat ini antara lain adalah sebagai berikut:

1. Peraturan Pemerintah Nomor 57 Tahun 2009 tentang Pengawasan Orang Asing dan Tindakan Keimigrasian

2. Undang-undang No. 6 tahun 2011 tentang 
Keimigrasian

3. Peraturan Pemerintah No. 31 tahun 2013 tentang Peraturan Pelaksanaan Undangundang Nomor 6 Tahun 2011 tentang Keimigrasian

4. Penjelasan Peraturan Pemerintah No. 31 tahun 2013

5. Peraturan Direktur Jenderal Imigrasi No. IMI-1489-UM-08-05 tahun 2010 tentang Penanganan Imigran Ilegal

(Sumber: Suaka, 2016)

Undang-Undang Keimigrasian tahun 2011 dibuat untuk menggantikan UU no 9 tahun 1992, dimana sebelum 1992, Indonesia tidak punya Undang-undang khusus Keimigrasian. UU tahun 2011 mengatur tentang masuknya orang asing ke Indonesia, dimana mereka diwajibkan membawa dokumen perjalanan yang sah ke Indonesia, dengan konsekuensi berupa rumah atau ruang detensi imigrasi bagi yang tidak dapat memenuhi persyaratan ini. Pasal 83 Ayat 1 UU no 6 tahun 2011 ini berbunyi:

1. "Pejabat Imigrasi berwenang menempatkan orang asing dalam Rumah Detensi Imigrasi atau Ruang Detensi Imigrasi jika Orang Asing tersebut:

2. a. berada di Wilayah Indonesia tanpa memiliki Izin Tinggal yang sah atau memiliki Izin Tinggal yang tidak berlaku lagi;

3. b. berada di Wilayah Indonesia tanpa memiliki Dokumen Perjalanan yang sah;

4. c. dikenai Tindakan Administratif Keimigrasian berupa pembatalan Izin Tinggal karena melakukan perbuatan yang bertentangan dengan peraturan perundangundangan atau mengganggu keamanan dan ketertiban umum;

5. d. menunggu pelaksanaan Deportasi; atau

6. e. menunggu keberangkatan keluar Wilayah Indonesia karena ditolak pemberian Tanda Masuk."

Pada dasarnya, hampir semua pencari suaka yang masuk ke Indonesia datang tanpa passport, visa atau dokumen perjalanan resmi dikarenakan situasi yang tidak memungkinkan ketika melarikan diri dari negara asalnya. Undang-undang ini dengan demikian tidak memadai karena pegungsi dan pencari suaka akan dengan mudah dikategorikan sebagai imigran yang melanggar hukum.

Sebelumnya pada tahun 2010 Dirjen Imigrasi telah mengeluarkan Peraturan Dirjen Imigrasi mengenai Penanganan Imigran Ilegal yang secara khusus mengatur mengenai imigran illegal yang merupakan pencari suaka. Disini dijelaskan bahwa pencari suaka "tidak dapat dikenakan pendeportasian, dikoordinasikan dengan organisasi internasional yang menangani masalah pengungsi dan/atau UNHCR untuk penentuan statusnya." Disini mereka mendapatkan keistimewaan dalam hal deportasi dan izin tanggal. Yang belum dibahas lebih lanjut disini adalah penggunaan rumah atau ruang detensi imigrasi seperti yang dijelaskan sebelumnya. Tetap digunakannya ruang atau rumah detensi imigrasi ini menyimbolkan penegakan kedaulatan Indonesia di atas 
hal-hal lainnya.

Selanjutnya, yang perlu diperhatikan adalah bahwa Undang-undang Keimigrasian kemudian mengkriminalisasi tindak penyelundupan manusia. di pasal 120 yang mengatur hukuma berupa ancaman pidana penjara sedikitnya lima tahun dan paling lama 15 tahun, dan pidana denda sedikitnya Rp 500 juta dan paling banyak Rp 1,5 milyar. Kriminalisasi penyelundupan manusia adalah hal yang wajar bagi suatu negara untuk menegaskan kedaulatan teritorialnya, dimana penyelundup dilihat sebagai aktor-aktor yang meniadakan arti negara dan hukum yang berlaku di dalamnya untuk kepentingan bisnis pribadinya.

Secara umum dapat disimpulkan bahwa keterkaitan antara konsep negara maritim dengan upaya penanganan penyelundupan manusi disini terbentuk ketika konsep negara maritim mengarahkan perhatian para pembuat kebijakan terhadap laut dan apa yang terjadi di dalamnya. Ketika potensi kelautan dipandang sebagai sumber kekuatan negara, tercipta persepsi mengenai ancaman kemanan dari luar baik itu dengan eksplorasi illegal sumber daya alam di lautan oleh negara lain atau sekedar lalu lintas manusia dan kapal. Tidak terkecuali disini adalah kapal yang mengangkut manusia yang bermigrasi akibat krisis kemanusiaan di negara asalnya. Mereka seringkali dilihat terutama dari aspek mode kedatangan yang tidak sesuai dengan aturan normal kenegaraan yang berlaku. Ketika mereka dilihat semata sebagai bentuk migrasi illegal, aspek kemanusiaan mereka cenderung dinomorduakan.

Bagian berikutnya tulisan ini membahas lebih jauh mengenai sikap Indonesia terkait penyelundupan manusia yang terlihat dalam kerjasama-kerjasama internasional yang dilakukan baik itu secara bilateral maupun regional.

\section{Kerjasama Luar Negeri Indonesia dalam Menangani Penyelundupan Manusia}

Pengambilan langkah berupa kerjasama luar negeri untuk penanganan masalah penyelundupan manusia adalah konsekuensi dari karakter transnasional dari penyelundupan manusia itu sendiri, dimana manusia yang diselundupkan ke dalam atau keluar Indonesia merupakan warga negara asing, yang dibantu (oleh penyelundup) yang bisa merupakan warga negara Indonesia atau warga negara asing. Disini ada dua aspek kerjasama yang akan menjadi fokus bahasan, yakni Bali Process on People Smuggling, Trafficking in Persons and Related Transnational Crime dan Lombok Treaty antara Indonesia dan Australia. Di samping itu, akan dibahas dinamika hubungan Indonesia dan Australia dalam isu-isu migrasi dan pengungsi untuk menggambarkan lebih jauh paradigma Indonesia mengenai keamanan dan kedaulatan serta pengungsi lintas batas.

\section{Bali Process 2002-2016}

Sebagai dua negara yang bertetangga dan dibatasi oleh Samudra Hindia, Indonesia dan Australia melihat urgensi dari kerjasama yang lebih konstruktif di bidang keamanan 
perbatasan. Salah satunya disini adalah dengan menyelenggarakan bersama pertemuan regional mengenai penhyelundupan manusia, perdagangan manusia dan tindakan criminal transnasional lainnya. Pada pertemuan pertama Bali Process tahun 2002, sejumlah negara dan organisasi internasional menghadiri pertemuan ini yakni Afghanistan, Bangladesh, Bhutan, Brunei Darussalam, Kamboja, Cina, Korea Selatan, Fiji, Perancis, India, Iran, Jepang, Jordan, Kiribati, Laos, Malaysia, Mongolia, Myanmar, Nauru, Nepal, Selandia Baru, Pakistan, Palau, Papua New Guinea, Filipina, Korea Utara, Samoa, Singapura, Kep. Solomon, Sri Lanka, Suriah, Thailand, Turki, Timor Leste, Vanuatu dan Vietnam, International Organisation for Migration (IOM) dan United Nations High Commissioner for Refugees (UNHCR). Dari pertemuan ini dihasilkan pernyataan CoChair yang secara umum mengatur mengenai kerangka kerjasama untuk menangani masalah migrasi tidak teratur ini.

Bila dilihat secara tekstual, pernyataan pertama Bali Process ini menyebutkan bahwa arus migrasi tidak teratur ini telah menghasilkan tantangan di bidang keamanan, politik, ekonomi dan sosial yang serius dalam setidaknya tiga hal:

1. aktivitas ini tidak mengindahkan kedaulatan dan batas-batas nasional.

2. aktivitas ini membahayakan HAM imigran aktivitas ini mengganggu kelancaran manajemen imigrasi.

(Sumber: Co-Chairs Statement, 2002)
Dokumen ini mempertegas aspek HAM dari masalah ini adalah ketika proses penyelundupan manusia dan perdagangan manusia yang menggunakan transportasi tidak resmi dan dilakukan pihak-pihak tidak bertanggungjawab yang mengambil keuntungan untuk dirinya sendiri ini sangat mengancam kehidupan orang-orang yang diselundupkan dan diperdagangkan. Hal itu memang dapat dilihat secara hitam putih dalam masalah perdagangan manusia dimana korban perdagangan manusia berpindah diluar kehendak pribadinya dan dalam banyak kasus pelaku menggunakan kekerasan terhadap korban. Berbeda kemudian dalam kasus penyelundupan manusia dimana orang-orang yang diselundupkan kebanyakan orang yang mencari suaka atau bermigrasi karena suatu alasan dan bergerak dengan kehendaknya sendiri. Penyelundup manusia disini hadir sebagai faktor yang memungkinkan pergerakan mereka, walaupun penyelundup juga mungkin mengeksploitasi mereka bila dilakukan penarikan biaya yang tinggi sementara mereka bergerak dengan transportasi yang tidak sah atau tidak aman.

Dalam dokumen ini, dan kemudian juga ditemukan dalam pernyataan Co-Chair di tahun-tahun berikutnya, dijelaskan bagaimana kesepakatan ini seharusnya tidak menganggu pemenuhan hak-hak pengungsi lintas batas. Lebih jauh lagi, pada Konferensi Regional tingkat Menteri tahun 2011 dibuat rekomendasi-rekomendasi seperti:

1. Imigran tidak teratur harus dilindungi 
2. Mereka yang ditemukan bukanlah pengungsi harus dipulangkan

3. Bisnis penyelundupan manusia harus disasar dengan kesepakatan mengenai keamanan perbatasan, penegakan hukum dan dis-insentif untuk perdagangan dan penyelundupan manusia.

(Sumber: Co-Chairs Statement, 2002)

Jadi, disini memang sudah dikemukakan bagaimana upaya menjaga keamanan perbatasan tidak boleh mengganggu pemenuhan HAM para pengungsi lintas batas. Namun dokumen tidak berhenti pada dokumen, kesepakatan internasional seperti di dalam dokumen-dokumen Bali Process, perlu dilihat bagaimana pengejewantahannya dalam kebijakan nasional atau praktek-praktek kerjasama yang dilakukan oleh negara yang terlibat. Kenyataannya, Australia sebagai salah satu negara penyelenggara utama Bali Process menerapkan berbagai kebijakan yang secara terang -terangan menolak kedatangan pengungsi lintas batas yang masuk melalui jalur-jalur laut. Lebih jauh akan dibahas pada dinamika hubungan Indonesia dan Australia terkait keamanan perbatasan.

Pada tahun 2016, Bali Process akhirnya menghasilkan Bali Declaration on People Smuggling, Human Trafficking and Other Transnational Crimes yang lebih jauh lagi mendeskripsikan mengenai langkah-langkah yang perlu dilakukan untuk perlindungan pengungsi lintas batas, yakni:

1.Perlindungan sementara dan pengaturan tempat tinggal lokal

2.Pengakuan akan kebutuhan akses bagi proses migrasi tidak teratur

3.Pembuatan alternatif dari detensi imigrasi Penyediaan tempat untuk resettlement bagi pengungsi lintas batas.

(Sumber: Bali Declaration, 2016)

Deklarasi Bali tahun 2016 merupakan pencapaian tertinggi sejauh ini dalam upaya mencapai jalan tengah antara penanganan penyelundupan manusia dengan perlindungan pengungsi lintas batas.

Makalah ini melihat bahwa Bali Process merupakan salah satu jalur yang diambil Indonesia dalam menjaga keamanan perbatasan lautnya, yakni melalui metode burden sharing dan peningkatan kapasitas dan penegakan hukum. Pada perkembangannya, Bali Process turut memberikan tantangan bagi pengungsi lintas batas dimana penekanan dari penanganan penyelundupan manusia adalah mengurangi intensitas proses migrasi itu sendiri, dimana migrasi pengungsi lintas batas adalah proses yang kompleks, dan upaya mengurangi arus pengungsi ke dalam suatu wilayah tidak akan membantu menyelesaikan krisis kemanusiaan yang mereka hadapi itu sendiri. Rumah dan ruang detensi imigrasi Indonesia yang terkait langsung dengan penanganan penyelundupan manusia mempertegas 'dis-insentif' bagi migrasi tidak teratur ini.

\section{Lombok Treaty}

Dikarenakan Indonesia dan Australia 
berbagi perbatasan laut, dan keduanya memiliki pandangan bahwa laut adalah sumber daya sekaligus sumber ancaman, kerjasama di antara keduanya menjadi sangat krusial untuk menjaga keamanan nasional dan perdamaian di antara keduanya. Salah satu kesepakatan bilateral yang berhasil dibuat berdasarkan pemahaman ini adalah Lombok Treaty yakni persetujuan yang dibuat tahun 2006 antara Republik Indonesia dan Australia dalam Kerangka Kerjasama Keamanan. Tujuan utamanya adalah meningkatkan kerjasama yang terkait dengan keamanan bersama dan keamanan masing-masing negara. Termasuk disini adalah untuk melawan terorisme dan bentuk tindakan kriminal transnasional lainnya. Di dalam persetujuan ini dicantumkan pokok-pokok kerjasama yakni di bidang:

1. Pertahanan, yakni dengan meningkatkan kerjasama pada peningkatan kapasitas melalui pendidikan militer, pertukaran dan kerjasama di bidang teknologi.

2. Penegakan Hukum, yakni untuk mencegah dan mengakhiri tindak criminal termasuk dalam penyelundupan manusia, money laundering, pembiayaan teroris, korupsi, perikanan illegal, tindak criminal cyber, perdagangan narkotika dan perdagangan senjata.

3. Counter-terrorisme, dengan memfasilitasi respon efektif dan cepat dalam menghadapi serangan teroris dan dengan memperkuat kerjasama intelijen dalam menghadapi terorisme.

Keamanan maritime, yakni dengan kerjasama bilateral dan peningkatan kapasitas di bidang keamanan maritime.

Lombok Treaty menjadi fondasi bagi kerjasama keamanan Indonesia-Australia pada tahun-tahun setelahnya, termasuk di dalamnya kerjasama keamanan maritim.

\section{Dinamika Hubungan Indonesia dan Aus- tralia dalam Isu Keamanan Maritim}

Setelah Lombok Treaty, berbagai pertemuan atau dialog antar pejabat IndonesiaAustralia telah dilakukan khusus membicarakan keamanan maritim ini. Di antaranya adalah Indonesia-Australia Defence Strategic Dialogue, "2+2" Foreign and Defence Minister's meeting, serta pertemuan pimpinan pasukan pertahanan masing-masing negara tahun 2013 (Supriyanto, 2014). Di tahun 2012, Perdana Menteri Jullia Gillard dan Presiden Susilo Bambang Yudhoyono melakukan pertemuan dan menekankan pentingnya penguatan ikatan maritime di antara keduanya untuk melawan penyelundupan manusia dan menghindari lebih banyak korban (Mercer, 2012). Di tahun 2016, Indonesia dan Australia melakukan patroli maritim bersama (Minister for Defence, 2016).

Hubungan Indonesia dan Australia ini kemudian diwarnai ketegangan ketika Australia memulai Operation Sovereign Borders tahun 2013 yakni "operasi keamanan perbatasan yang dipimpin oleh pihak militer yang bertujuan untuk membasmi penyelundupan manusia dan melindungi batas-batas negara Australia" (Department of Immigration and Border Protection, 2016). Australia juga kemudian 
memiliki kebijakan menolak migran yang datang dengan kapal atau perahu tanpa visa, dikenal dengan slogan, "No way, they will not make Australia home" pada pemerintahan Tony Abbot. Sebagai implementasi dari kebijakan ini, Australia beberapa kali mengirim kapal yang mengangkut migran keluar perbatasannya atau ke Indonesia. Indonesia menanggapi perkembangan ini sebagai cara Australia "mengalihkan beban dan tanggung jawab kembali ke Indonesia" (Kleib, dikutip oleh Aljazeera, 2015).

Secara umum, perkembangan kerjasama maritime yang dilakukan Indonesia dengan Australia menunjukkan arah yang sama dengan Bali Process dan Lombok Treaty, yakni meletakkan isu penyelundupan manusia dalam ranah kedaulatan dan keamanan nasional. Retorika ini kemudian menciptakan pandangan bahwa kedatangan migran tidak teratur seperti ini harus dikurangi untuk menjaga kestabilan.

\section{Kesimpulan}

Konsep Negara Maritim berbicara tentang maksimalisasi penggunaan sumber daya yang ada di laut untuk pemenuhan kesejahteraan warga negara, serta pengarusutamaan cara pandang ini dalam pembuatan kebijakan. Konsepsi "Poros Maritim Dunia" yang saat ini sedang dibawakan oleh pemerintahan Joko Widodo, hadir menggantikan pola berpikir lama yang berorientasi "kontinental" atau kepulauan. Penekanan Poros Maritim Dunia adalah kepada pemanfaatan kembali laut untuk kema- juan ekonomi dan kesejahteraan masyarakat secara keseluruhan.

Persepsi mengenai laut sebagai tempat hidup dan sumber kehidupan ini pada akhirnya juga akan diikuti oleh persepsi yang kuat mengenai keamanan, pertahanan dan kedaulatan. Menjaga agar sumber daya dapat diserap secara utuh oleh negara untuk warga negara akan membutuhkan kekuatan penjagaan wilayah laut. Dan untuk memastikan negara lain 'menghormati' wilayah laut ini, dibutuhkan persepsi keluar yang kuat mengenai kedaulatan negara. Pada titik inilah Indonesia rawan mengkompromikan komitmen kemanusiaannya terkait perlindungan pengungsi, yakni ketika kedaulatan dijaga dengan langkah-langkah yang cenderung bersifat men-deter kedatangan pengungsi, dan ketika retorika kedaulatan tidak diikuti retorika mengenai hak asasi manusia seorang pengungsi di Indonesia.

Sikap Indonesia yang cenderung mencegah kedatangan lebih banyak pengungsi lintas batas dengan jalur tidak teratur tercermin dalam penggunaan kebijakan imigrasi dalam menangani pengungsi-pengungsi lintas batas yang datang secara illegal serta dalam hubungan bilateralnya dengan Australia di bidang penanganan imigran illegal di jalur laut, baik itu dalam wujud kerjasama maupun konflik. Secara tidak langsung, kebijakan-kebijakan ini berpengaruh kepada pemenuhan hak pengungsi untuk bebas bergerak atau masuk ke sebuah negara. Sementara itu retorika mengenai HAM belum tercermin dalam kebijakan Indonesia 
mengenai pengungsi secara keseluruhan. Disini kita berbicara mengenai ketidakikutsertaan Indonesia pada Konvensi Jenewa tahun 1951 mengenai Status Pengungsi Lintas Batas. Tanpa menandatangani Konvensi ini, dimata hukum internasional, Indonesia tidak memiliki kewajiban dalam melindungi pengungsi lintas batas ini.

Perlu diakui bahwa tanpa kewajiban inipun, Indonesia sebenarnya sudah mulai mengambil peran cukup aktif yakni dengan memberlakukan ijin tinggal bagi pengungsi lintas batas yang belum mendapatkan status pengungsinya atau belum mendapatkan negara ketiga yang mau menampungnya. Di samping itu, terdapat berbagai inisiatif lokal yang telah berupaya mendobrak batasan-batasan yang ada terhadap perlindungan pengungsi. Hal yang masih menjadi batasan adalah penggunaan rumah-rumah detensi imigrasi yang merupakan instrumen dari kebijakan imigrasi sekaligus kebijakan terkait keamanan perbatasan. Secara umum, pengalaman Indonesia menunjukkan bagaimana negara terjebak di antara hospitality dan sovereignty seperti dijelaskan oleh Benhabib (2004).

Ke depannya, Indonesia sebagai negara dapat meningkatkan komitmennya terhadap HAM dari pengungsi lintas batas dengan mencari alternatif dari rumah detensi imigrasi, serta dengan turut menyuarakan di forum-forum internasional bagaimana menciptakan jalur migrasi yang aman bagi para pengungsi lintas batas.

\section{Daftar Pustaka}

Aljazeera. (2015). Indonesia Blasts A ustralia for Pushing Back Boat. Diunduh pada 4 November 2016 dari http://www.aljazeera.com/news/2015/11/indonesia-blasts-australia-pushing-boat $-151127051503210 . h t m l$

Bali Declaration on People Smuggling, Trafficking in Persons and Related Transnational Crime: The Sixth Ministerial Conference of the Bali Process on People Smuggling, Trafficking in Persons and Related Transnational Crime, diunduh pada 4 November 2016 dari http:// baliprocess.net

Bali Ministerial Conference on People Smuggling, Trafficking in Persons and Related Transnational Crime Co-Chairs' Statement 26-28 February 2002, diunduh pada 4 November 2016 dari http://baliprocess.net

Benhabib, S. (2004). The Rights of Others: Aliens, residents and Citizens. New York: Cambridge University Press.

. (2006). The Philosophical Foundations of Cosmopolitan Norms. Dalam Benhabib, S. (Ed.). Another Cosmopolitanism (pp. 13-44). New York: Oxford University Press. 
Chandler, D. (2002). The Limits of Human Rights and Cosmopolitan Citizenship. dalam Chandler, D. (Ed). Rethinking Human Rights (pp. 115-135). London: PalgraveMacmillan.

Department of Immigration and Border Protection. (2016). Operation Sovereign Borders. Diunduh 4 November 2016 dari http://www.osb.border.gov.au/

Fifth Ministerial Conference Of The Bali Process On People Smuggling, Trafficking In Persons And Related Transnational Crime Bali, Indonesia, 2 April 2013 Co-Chairs' Statement, diunduh pada 4 November 2016 dari http://baliprocess.net

Fourth Bali Regional Ministerial Conference On People Smuggling, Trafficking In Persons And Related Transnational Crime Bali, Indonesia, 29-30 March 2011 Co-Chairs' Statement, diunduh pada 4 November 2016 dari http://baliprocess.net

Haddad, E. (2003). The Refugee: the Individual Between Sovereigns. Global Society, 17 (3), 297 332.

. (2008). The Refugee in International Society: Between Sovereigns. Cambridge: Cambridge University Press.

Human Rights Watch, 2013. Indonesia: Anak-anak yang mencari suaka menemukan kekerasan dan penelantaran. Diunduh pada November 2016 dari https:/www.hrw.org/id/ news/2013/06/23/250191

Mercer, P. (2012). People Smuggling Dominate Indonesia-Australia Talks. Voice of America. Diunduh 12 Desember 2012 dari http://www.voanews.com/content/people-smugglersdominate-australian-indonesian-talks/1360657.html

Migrant Rights Network. (2009). Irregular Migrants: An Urgent Need for A New Approach. Diunduh 14 November 2016 dari http://www.migrantsrights.org.uk/downloads/ policy_reports/irregularmigrants_fullbooklet.pdf

Minister for Defence. (2016). The fourth Indonesia-Australia Foreign and Defence Ministers $2+2$

Dialogue Joint Comunique. Diunduh pada 14 November 2016 dari http://

www.minister.defence.gov.au/2016/10/27/minister-for-defence-the-fourth-indonesiaaustralia-foreign-and-defence-ministers-22-dialogue/

Minister for Foreign Affairs. (2015). Joint Communiqué - Third Australia-Indonesia Foreign and Defence Ministers 2+2 Dialogue. Diunduh pada 1 November 2016 dari http:// foreignminister.gov.au/releases/Pages/2015/jb_mr_151221.aspx

Refugee Council. (2015). Diunduh pada 10 Oktober 2016 dari http://www.refugeecouncil.org.au/ getfacts/statistics/unchr2015/

Rosyid, D. M. (2015). Strategi dan Kebijakan Maritim Indonesia. Dalam Susilo, I. B. (Ed). (2015). Kemaritiman Indonesia: Problem Dasar Strategi maritime Indonesia. Surabaya dan Malang: CSGS dan Intelegensi Media. 
Suaka. (2016). Legal Source of Related Refugee Protection in Indonesia. Diunduh pada 14 November 2011 dari https://suaka.or.id/news/legal-source-of-related-refugee-protection-inindonesia/

Supriyanto, R. A. (2014). Waves of opportunity: Enhancing A ustralia-Indonesia maritime security cooperation. Diunduh pada 14 November 2016 dari https://www.aspi.org.au/ publications/waves-of-opportunity-enhancing-australia-indonesia-maritime-securitycooperation/SI79_Aus_Indon_maritime_cooperation.pdf

Susanto, J. (2015). Evolusi Strategi Maritim Indonesia. Dalam Susilo, I. B. (Ed). (2015). Kemaritiman Indonesia: Problem Dasar Strategi maritime Indonesia. Surabaya dan Malang: CSGS dan Intelegensi Media.

Third Bali Regional Ministerial Conference On People Smuggling, Trafficking In Persons And Related Transnational Crime Bali, Indonesia, 14-15 APRIL 2009, Co-Chairs' Statement, diunduh 